$11-1-2011$

\title{
From Policy to Practice: Implementation of the Legislative Objectives of Charter Schools
}

Katherine M Barghaus

University of Pennsylvania

Erling E. Boe

University of Pennsylvania, boe@gse.upenn.edu

Follow this and additional works at: https://repository.upenn.edu/gse_pubs

Part of the Education Policy Commons, and the Other Education Commons

\section{Recommended Citation}

Barghaus, K., \& Boe, E. E. (2011). From Policy to Practice: Implementation of the Legislative Objectives of Charter Schools. Retrieved from https://repository.upenn.edu/gse_pubs/242

Barghaus, K. M., \& Boe, E. E. (2011). From policy to practice: Implementation of the legislative objectives of charter schools. American Journal of Education, 118(1), 57-86. doi: 10.1086/662009

This paper is posted at ScholarlyCommons. https://repository.upenn.edu/gse_pubs/242

For more information, please contact repository@pobox.upenn.edu. 


\title{
From Policy to Practice: Implementation of the Legislative Objectives of Charter Schools
}

\author{
Abstract \\ Key legislative objectives of charter schools are to provide more school and classroom options, increase \\ teacher influence over decision making, and increase school autonomy from state and district policy. \\ Using national data from the 2003-4 School and Staffing Survey, we found that charter schools attained \\ these legislative objectives when compared with regular schools, although increases in teacher influence \\ and school autonomy were modest. Although charter schools have been implemented much as intended \\ by legislation, other research has shown that charter schools in general have not improved student \\ achievement-a major objective of charter school legislation. Our results suggest that this cannot be \\ attributed to a failure to implement the charter school concept with respect to the legislative objectives \\ examined.

\section{Disciplines} \\ Education | Education Policy | Other Education

\section{Comments} \\ Barghaus, K. M., \& Boe, E. E. (2011). From policy to practice: Implementation of the legislative objectives \\ of charter schools. American Journal of Education, 118(1), 57-86. doi: 10.1086/662009
}




\title{
From Policy to Practice: Implementation of the Legislative Objectives of Charter Schools
}

\author{
KATHERINE M. BARGHAUS \\ University of Pennsylvania \\ ERLING E. BOE \\ University of Pennsylvania
}

\begin{abstract}
Key legislative objectives of charter schools are to provide more school and classroom options, increase teacher influence over decision making, and increase school autonomy from state and district policy. Using national data from the 2003-4 School and Staffing Survey, we found that charter schools attained these legislative objectives when compared with regular schools, although increases in teacher influence and school autonomy were modest. Although charter schools have been implemented much as intended by legislation, other research has shown that charter schools in general have not improved student achievementa major objective of charter school legislation. Our results suggest that this cannot be attributed to a failure to implement the charter school concept with respect to the legislative objectives examined.
\end{abstract}

The charter concept was first articulated by Ray Budde, a retired school teacher, and Albert Shanker, a past president of the American Federation of Teachers (Nathan 1998). Budde used the term "charter" to describe a contract granted to a group of teachers by a local school board to allow them to explore new educational approaches (Nathan 1998). He formalized this concept in a 1988 report titled Education by Charter: Restructuring School Districts (Budde 1988). That year, Shanker published a report outlining several important needs of American schools including flexibility in terms of structure and more accountability. To meet these needs, Shanker (1988) suggested creating public "charter" schools, which would be voluntary, innovative schools periodically evaluated to determine whether they were meeting their goals and should continue. In 1989, Philadelphia started several schools-within-schools, some of which were schools of choice, and referred to them as "charters" (Nathan 1998; Sautter 1993). However, it would take another decade before major

Electronically published September 23, 2011

American Journal of Education 118 (November 2011)

(C) 2011 by The University of Chicago. All rights reserved.

0195-6744/2011/11801-0003\$10.00 


\section{Charter School Legislative Objectives}

federal legislation would bring the charter school concept to scale on a national level.

The National Assessment of Educational Progress (NAEP) defines a public charter school (herein referred to simply as a charter school) as "a publicly funded school that, in accordance with an enabling state statute, has been granted a charter exempting it from selected state or local rules and regulations" (NAEP 2008, http://nces.ed.gov). In 1991, Minnesota was the first state to pass charter school legislation that articulated several objectives, including implementing innovative teaching methods and improving student learning (Schroeder 2004). A year later, Minnesota opened the first public charter school in the United States (St. Paul's City Academy High School), which still operates today. Charter schools have flourished since 1992, and today there are over 5,000 charter schools serving approximately 1.5 million students in 39 states and Washington, DC (Center for Education Reform [CER] 2009). Growth in the number of charter schools since 1992 is shown in figure 1 .

\section{Background}

\section{Legislative Objectives of Charter Schools}

As the number of states authorizing charter schools has grown over the years, so have the number of legislative objectives for charter schools. According to a report by the National Alliance for Public Charter Schools, the "most objective way to identify the original goals of the charter school movement is to go back to the text of the laws that actually started it . . . i.e., the purposes of chartering" (Smarick 2005, 1). The report ranked the frequency with which 18 unique objectives appeared in state charter school laws. The two major objectives found in over 90 percent of state laws were to provide more school options for all families (94 percent) and to improve the academic achievement of all students (91 percent; Smarick 2005). The U.S. Department of Education (USDE) also specifies these objectives in its financial support of charter schools

KATHerine M. BARghaus is a doctoral student at the University of Pennsylvania, Graduate School of Education, and an Institute of Education Sciences (IES) predoctoral fellow. Her main research interests are in early childhood education, gender and education, and psychometrics. ERLING E. BOE is a professor of education at the University of Pennsylvania and co-director of the Center for Research and Evaluation in Social Policy. He has written widely on national issues and research on teacher supply, demand, shortage, turnover, and quality. 


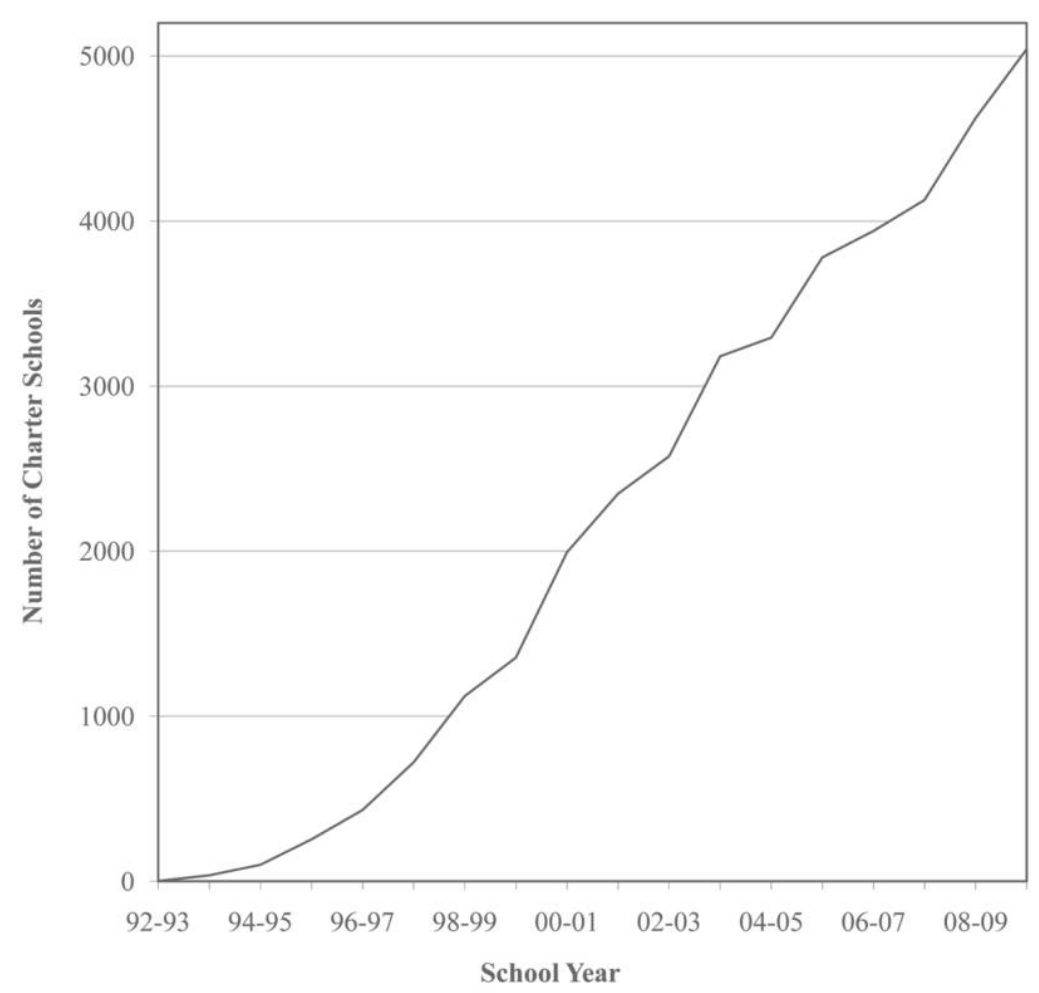

FIG. 1.-Number of charter schools in the United States by school year. Source: Common Core Data, NCES, USDE, for years 1992-93 through 2005-6; Center for Education Reform for years 2006-7 through 2009-10.

(USDE 2004a). In addition to providing more school options and improving achievement, other frequently cited objectives of charter schools are to increase teacher influence over decision making and increase school autonomy from outside influences such as the state and local school district (Smarick 2005). Because others have studied student achievement in charter schools, it will not be examined again here (for a review see Hill, Angel, and Christensen 2006). The main purpose of this article is to examine the implementation of three major non-achievement-focused legislative objectives of charter schools (i.e., providing more options, increasing teacher influence, and increasing school autonomy). ${ }^{1}$ 


\section{Charter School Legislative Objectives}

\section{Objective: Provide More School and Classroom Options}

One of the most frequently cited objectives of charter school legislation is to provide more school options for all families (94 percent of states with charter school laws; Smarick 2005). "Charter schools are . . o often touted by politicians as examples that the traditional system of public education is not the only option" for families (Bulkley and Fisler 2003, 318). However, providing more options does not necessarily imply something different or new is being offered (while "more innovations" would): more options could simply mean more choices are provided. We use this definition and examine the options charter schools offer at the school (e.g., program emphasis) and classroom level (e.g., block scheduling).

Much research on the school and classroom options that charter schools create has used data from single states or multiple cities (e.g., Mintrom [2000], for Michigan; Miron and Horn [2003], for Connecticut; Miron and Nelson [2000], for Pennsylvania; Schroeder [2004], for Minnesota; Teske et al. [2000], for cities in Massachusetts, New Jersey, and DG). In addition, this research does not always draw comparisons between charter schools and traditional public schools (herein referred to as regular schools; see, e.g., Division of Charter Schools and Texas Education Agency [2007], for Texas; Gifford, Phillips, and Ogle [2000], for Arizona; Triant [2001], for Massachusetts). Lubienski (2003) did an exhaustive review of the literature on options in charter schools and found that they offer alternatives in areas such as class size, technology, and educational programs. Lubienski also found that, with few exceptions, charter schools employ the same curricular and instructional approaches used in regular schools.

A few studies have examined this issue using information from multiple states or national level data (e.g., American Federation of Teachers 2002; National Charter School Research Project 2007). Strizek et al. (2006) investigated talented/gifted programs and classroom organization options offered in regular and charter schools using data from the 2003-4 Schools and Staffing Survey (SASS). They compared all charter schools to all regular schools in the United States and found that charter schools were more likely than regular schools to use special instructional approaches, looping, block scheduling, and small student groups. They also found that charter schools were less likely than regular schools to offer talented/gifted programs. However, the researchers noted that "more sophisticated analyses can be conducted with the restricted-use version of the SASS data" (Strizek et al. 2006, 2).

Despite this research, two recent literature reviews concluded that little is known about the number or types of nontraditional or alternative programs offered in charter schools across the nation and how they compare with regular schools in these respects (Bulkley and Fisler 2003; Gill et al. 2007). Thus, the 
degree to which charter schools have provided more choices with respect to educational programmatic emphasis and classroom practices is worthy of further research (Gill et al. 2007). To that end, this study investigates the following two research questions:

Research question 1: Have charter school laws created more types of school options compared with those offered by regular schools?

Research question 2: Have charter school laws created more nontraditional classroom options than those used in regular schools?

\section{Objective: Increase Teacher Influence}

Another charter school legislative objective is to afford teachers more influence over decision making in their schools (specified in 62 percent of state charter school laws; Smarick 2005). This objective intends to allow teachers to "better attend to student needs and implement best practices in the classroom, thereby improving student achievement" (Gawlik 2007, 549). Teacher influence has been defined as making teachers decision makers within schools by giving them control over the curriculum, budget, the hiring of colleagues, and monitoring the performance and hiring of administrators (Dirkswager 2002). We used this to inform our definition of teacher influence over decision making.

The extent of teacher influence over decision making within charter schools is unknown (Gawlik 2007). The research on teacher influence in charter schools includes mostly single-state studies and case studies rather than national level studies, and the results are mixed. Some studies have found that charter school teachers report having influence over classroom or pedagogical decisions (e.g., Bomotti, Ginsberg, and Cobb 1999; Malloy and Wohlstetter 2003). For example, Bomotti et al. (1999) interviewed charter and regular school teachers in Colorado and discovered that charter school teachers reported greater influence over classroom decisions such as disciplining students and setting policy on the grouping of students. However, others have found that the perception of influence varies by state and school (Gawlik 2007). Crawford (2001) and Crawford and Forsyth (2004) surveyed charter and regular school teachers in Colorado and Michigan and found that charter school teachers in Colorado perceived less influence than regular school teachers; however, no difference was found in Michigan.

The research on teacher influence over decision making is inconclusive and not generalizable nationally. There is a need for national studies to quantify the extent to which charter schools provide teachers with more influence compared with that afforded to teachers in regular schools. Thus, this study also investigates the following research question: 


\section{Charter School Legislative Objectives}

Research question 3: Have charter school teachers experienced increased influence over decision making in their schools in comparison with regular school teachers?

\section{Objective: Increase School Autonomy}

It is difficult to draw conclusions and generalizations from the literature about the level of charter school autonomy because there is no established, universal definition of autonomy (Finnigan 2007). The review of research below demonstrates the lack of consensus in the definition of autonomy and in the findings pertaining to the level of autonomy that charter schools experience. Although the definitions of autonomy vary in their details, they generally encompass the ability of individual schools to make decisions about budgeting, hiring, and the educational program (Bulkley and Fisler 2002). This article investigates charter school autonomy from state and district influence over decision making related to the budget, personnel, curriculum, instruction, and school policy.

The literature on charter school autonomy includes several national studies. From 1995 to 1999, the USDE sponsored a national evaluation of the charter school movement. Charter school administrators were interviewed, and most (77 percent or more) reported that they had primary control over purchasing, hiring, scheduling, disciplinary policies, and curriculum, while slightly fewer (between 60 and 73 percent) reported control over budgets, student assessment, and admissions (RPP 2000). The USDE funded another evaluation from 1999 to 2002, which surveyed charter school authorizers, directors, principals, and other administrators about their perceptions of autonomy. The results indicated that charter schools had full authority over scheduling, purchasing, budgets, staff decisions, and disciplinary policies (Anderson et al. 2002; USDE 2000, 2004b). Using the 1999-2000 SASS, Gawlik (2008) found that charter school principals had greater autonomy than public school principals over performance standards, curriculum, professional development, staffing decisions, disciplinary policies, and the budget. More recently, Brinson and Rosch (2010) graded the autonomy extended by charter laws over school culture, instructional program, staffing decisions, finance, and governance in 26 states. In contrast with past research, this study found that the combination of state laws and regulations imposed by authorizing agencies placed significant restrictions on charter schools.

These national studies demonstrate a lack of consensus on the level of autonomy experienced by charter schools. Furthermore, only Gawlik (2008) compared charter school autonomy to regular schools. However, data for that study were from 1999 and 2000, making the findings not as generalizable to the current state of affairs. The most recent study by Brinson and Rosch (2010) 
relied primarily on analyzing documents to assess the level of charter school autonomy rather than on reports of autonomy from charter school principals who are directly involved in decision making. Our research addresses all of these shortcomings by using more recent data collected from both charter and regular school principals.

Studies of charter school autonomy performed at the state rather than national level also yield mixed results. Zimmer et al. (2003) surveyed charter and regular school principals in California about their control over the curriculum, budget, staffing decisions, student assessment, and disciplinary policies. The results indicated that charter schools had greater autonomy than regular schools in all areas. Finnigan (2007) also examined the level of autonomy experienced by charter schools - measured by the degree of deregulation from higher levels of government and school-level control over scheduling, purchasing, and staffing decisions. Using data from the 2004 USDE study cited above and from case studies of charter schools in six states, Finnigan concluded that many charter schools do not have high levels of autonomy. Finally, Wells et al. (1998) interviewed district officials, school leaders, teachers, and governance council members in California charter schools about the support and services they receive from the district, nondistrict sources of support, and the school's control over staffing decisions. They found that charter schools varied greatly in their level of autonomy, but that most had considerable control over staffing decisions (Wells et al. 1998).

The extent to which charter school principals actually experience greater autonomy over school management than regular school principals is unclear. This is a critical test of whether the implementation of charter school legislation actually engenders greater school autonomy as intended. Further study of charter and regular school principals' reports of the level of school autonomy will provide a better understanding of the implementation of this legislative objective. Consequently, this study investigates the following research question:

Research question 4: Have charter school principals experienced more autonomy from state and district influence over school operations than regular school principals?

Method

Data Source

The data for this study come from the restricted-use 2003-4 Schools and Staffing Survey (SASS) conducted by the National Center for Education Sta- 


\section{Charter School Legislative Objectives}

tistics (NCES), USDE. SASS is the largest survey in the United States of public (including public charter), private, and Bureau of Indian Affairs schools, and their teachers and principals (Tourkin et al. 2007). The school questionnaire includes information on grade level, student enrollment, and programs offered. The teacher questionnaire collects data such as teachers' qualifications, responsibilities, and influence over instruction. The principal questionnaire asks about principals' qualifications, perceptions about school decision-making authority, and so forth. The various questionnaires administered for the SASS provide a unique collection of variables not offered in other data sets such as the NCES Common Core Data. For example, the SASS asks many questions about the influence that teachers, principals, states, and school districts have over decision making.

The large national-probability samples used by SASS generated the following samples (with weighted response percentages) of public schools, teachers, and principals for analyses: 7,991 schools (81 percent), 43,244 teachers (85 percent), and 8,143 principals (82 percent; Tourkin et al. 2007). Since this article focuses on national and state level charter school policies, this large national-probability sample provides data that aligns with this goal.

\section{Definitions of a Regular Public School, Charter School, Teacher, and Principal}

According to definitions used by the SASS (Tourkin et al. 2007), a regular school has an assigned principal, receives public funding as its primary support, provides free public elementary and/or secondary schooling, and is operated by a local education agency or a contracted education program. A charter school is a public school that, in accordance with an enabling state statute, has been granted a charter exempting it from select state or local rules and regulations. A charter school may be a newly created school, or it may previously have been a regular or private school.

A teacher is defined as any individual who reported being employed either full time or part time at a public school (including a public charter school) with a main assignment to teach in any $\mathrm{K}-12$ grade(s). This includes itinerant teachers and long-term substitutes (Tourkin et al. 2007). Excluded from this definition are individuals who identified their main assignment as a pre-kindergarten teacher, short-term substitute, student teacher, teacher aide, or a nonteaching specialist. Finally, a principal is defined as any individual appointed as head of a school (Tourkin et al. 2007). 
School, Teacher, and Principal Samples

As of 2003-4, about 3,200 charter schools were operating in 37 states and Washington, DC (see fig. 1). Of these, the SASS collected school information from a national probability sample of 230 charter schools located in 27 states and DC. For this research, we selected states with at least 3 charter schools in the SASS, yielding a study sample of 220 charter schools located in 17 states and DC. These charter schools were compared with the full sample of 2,860 regular public schools in these same states. States represented in this sample were Arizona, California, Colorado, Florida, Hawaii, Massachusetts, Michigan, Minnesota, New Jersey, New York, North Carolina, Ohio, Oregon, Pennsylvania, South Carolina, Texas, and Wisconsin. We also used data from the teachers (1,090 charter and 15,650 regular) and principals (220 charter and 2,910 regular) in these schools.

\section{Design}

This research was designed to quantify and analyze, from the perspective of states with charter schools, the extent to which charter schools have implemented three of their most prominent legislative objectives (providing more types of schools and nontraditional classroom options, increasing teacher influence over decision making, and increasing school autonomy from state and district influence) in comparison with that observed in regular schools in the same states. Accordingly, charter schools were compared with regular schools in terms of a number of indicators of these three prominent legislative objectives described below.

\section{School Option Indicators: Types of Schools}

Indicators of the types of schools made available to students are as follows:

Type of school.-All elementary and secondary schools were classified as one of five types: (1) a school offering a traditional program, (2) a school with a special program emphasis (such as a science/math, gifted, or foreign language immersion school), (3) a special education school (mainly serving students with disabilities), (4) a vocational/technical school (primarily offering occupationspecific training), or (5) an alternative school (offering a nontraditional education, which does not fall into one of the aforementioned categories; Tourkin et al. 2007). The majority of alternative schools served students "at risk" of not completing their education. Special education and vocational/technical 


\section{Charter School Legislative Objectives}

schools were not analyzed here, because very few charter schools were of these types.

Talented/gifted program or honors courses. - This is a dichotomous variable (yes/ no), indicating whether a school offers a program designed for students with specific talents or exceptional academic achievement.

\section{School Options Indicators: Nontraditional Classroom}

Indicators of classroom options are as follows:

Special instructional approach.-This is a dichotomous variable (yes/no) indicating whether a school offers a program with a special instructional approach such as Montessori, self-paced instruction, or ungraded classrooms (Tourkin et al. 2007).

Looping.- This is a dichotomous variable (yes/no) indicating whether students remain with the same teacher for two or more years.

Block scheduling.- This is a dichotomous variable (yes/no) indicating whether a school schedules class periods to create extended instructional time.

Small student groups.-This is a dichotomous variable (yes/no) indicating whether a school subdivides grades or students into small groups called "houses," "families," or "teams."

\section{Teacher Influence over Decision-Making Indicator}

Indicators of teacher influence over decision making are as follows:

Influence over decision making. - Teachers were asked how much influence they had over decision making in seven areas: (1) setting performance standards for students, (2) establishing curriculum, (3) determining the content of inservice professional development, (4) evaluating teachers, (5) hiring new fulltime teachers, (6) setting discipline policy, and (7) deciding how the school budget will be spent. Answers were given on a 4-point scale indicating either no, minor, moderate, or a great deal of influence for each of the seven areas. Teachers' responses to each of these items were summed and organized in a frequency distribution. A three-level variable was created with the lowest and highest levels corresponding to the first and fourth quartiles of the distribution. The three levels of the variable correspond to considerable, some, and little teacher influence. The combination of responses to these seven items yielded a Cronbach's alpha of .81, indicating that our measure has a high level of reliability or internal consistency (Cronbach 1951).

Control over curriculum.- - Teachers were asked how much control they thought 
they had in their classroom to select the content, topics, and skills they would teach. Answers were given on a 4-point scale indicating no, minor, moderate, or a great deal of influence. Teachers' responses were organized in a frequency distribution, and a three-level variable was created with the lowest and highest levels corresponding to the first and fourth quartiles of the distribution. The three levels of the variable correspond to considerable, some, and little teacher control.

Control over instruction.- - Teachers were asked how much control they thought they had in their classroom over selecting teaching techniques. Answers were given on a 4-point scale indicating no, minor, moderate, or a great deal of influence. Teachers' responses were organized in a frequency distribution, and a three-level variable was created with the lowest and highest levels corresponding to the first and fourth quartiles of the distribution. The three levels of the variable correspond to considerable, some, and little teacher control.

\section{School Autonomy Indicator}

The indicators for school autonomy are as follows:

State influence over school operations. - Principals were asked how much influence they thought the state department of education (or other state-level body) had over school operations in seven areas: (1) setting performance standards for students, (2) establishing curriculum, (3) determining the content of in-service professional development, (4) evaluating teachers, (5) hiring new full-time teachers, (6) setting discipline policy, and (7) deciding how to spend the school budget. Answers were given on a 4-point scale, indicating no, minor, moderate, or major influence for each of the seven areas. Principals' responses to each of these items were summed and organized in a frequency distribution. A three-level variable was created with the lowest and highest levels corresponding to the first and fourth quartiles of the distribution. The three levels of the variable correspond to considerable, some, and little state influence. The combination of responses to these seven items yielded a Cronbach's alpha of .77, indicating that our measure has a high level of reliability or internal consistency (Cronbach 1951).

District influence over school operations. - Principals were asked how much influence they thought the school district staff had over school operations in the seven areas described above in State Influence over School Operations. A three-level variable was created with the lowest and highest levels corresponding to the first and fourth quartiles of the distribution. The three levels of the variable correspond to high, considerable, and some district influence. The combination of responses to these seven items yielded a Cronbach's alpha of .78. 


\section{Charter School Legislative Objectives}

\section{Analysis Procedures}

Using the samples of public charter and regular schools, teachers, and principals, we computed national estimates of the weighted numbers of schools, teachers, and principals of each type (along with associated percentages and standard errors) using special procedures developed by NCES for complex sample survey data (Tourkin et al. 2007). Because the SASS data are subject to design effects due to stratification and clustering of the sample, we computed standard errors for the national estimates and tests of statistical significance using balanced repeated replications with the JACKREG program (May 2004), which is the same method used by WesVar (Westat 2002). We used logistic regression to compute an effect size statistic (odds ratios [ORs]) of the differences observed between charter and regular schools, teachers, and principals, and to test the statistical significant of these differences (Hosmer and Lemeshow 2000; May 2004). ${ }^{2}$

\section{Limitations}

Since our results are based on large national-probability samples of schools, teachers, and principals, they should not be interpreted as directly applicable to the state or local level unless supported by other data from the relevant level. For example, the attainment of the legislative objectives of charter schools might be greater in some states than in others - a topic for further research. In addition, the SASS data are from self-reports of school personnel and therefore subject to errors of recall and bias. Finally, as with all sample data such as SASS, the reported estimates are subject to sampling error, as well as to measurement and recording error.

For the past decade, the GER has ranked the states based on the strength of their charter school laws. The laws of each state receive a grade based on a dozen criteria including the ability of charters to operate without burdensome legal, operational, and fiscal controls (CER 2006). According to the CER rankings, 83 percent of states in our sample are considered to have stronger charter school laws. States with "stronger" laws in the CER ranking system have more deregulation and provide more opportunities for a large numbers of charter schools to open. Thus, the effects we find here are primarily pertinent to states with stronger laws.

Because CER advocates for school choice and the advancement of the charter school movement, we do not cite their views and recommendations here. The CER's analysis of the content of state charter school laws was cited to provide one measure of the strength of such laws in the states in our sample. 
It should also be noted that there is no evidence that "stronger" laws produce higher quality or better performing charter schools.

\section{Results}

\section{School Options: Types of Schools}

With respect to the charter school legislative objective to provide more school options, figure 2 shows the proportion of charter and regular schools of three types (traditional, special emphasis, and alternative). Eighty-six percent of regular schools offered a traditional educational program compared with only 54 percent of charter schools $(\mathrm{OR}=5.3, p<.001)$. By comparison, charter schools were about five times more likely $(\mathrm{OR}=4.6, p<.001)$ to offer special emphasis programs than regular schools. Likewise, charter schools were also much more likely than regular schools $(\mathrm{OR}=4.5, p<.001)$ to offer alternative programs. In these respects, charter schools offered more school options than regular schools.

The results for the special emphasis program variable described above aggregated several diverse types of programs, including talented/gifted programs. ${ }^{3}$ Comparing the proportion of charter and regular schools specifically offering talented/gifted programs is of interest because charter schools have been accused of "creaming" (i.e., recruiting high-achieving students). If this were true, then one would expect charter schools to be more likely to offer a talented/gifted program. However, as shown in figure 2, regular schools were almost four times more likely to offer talented/gifted programs than charter schools (70 vs. 38 percent, respectively; $\mathrm{OR}=3.8, p<.001$ ).

A possible reason for the higher percentage of regular schools offering talented/gifted programs than charter schools is that regular schools are, on average, considerably larger than charter schools (median of 550 vs. 250 students, respectively, in our sample). Regular schools therefore have better capacity to offer a specialized program of this type. Accordingly, we classified schools as small (390 or fewer students) and large (more than 390 students) ${ }^{4}$ and computed a logistic regression with the talented/gifted program variable, the school size variable, and the interaction between them as predictors of school type (charter vs. regular). The two predictor variables and their interaction were all highly statistically significant. In this multivariate model, the adjusted OR for talented/gifted programs was reduced to 2.0 from 3.8 in the unadjusted bivariate model.

Given the interaction, we analyzed the results separately for small and large schools. Small regular schools were twice as likely as small charter schools to 


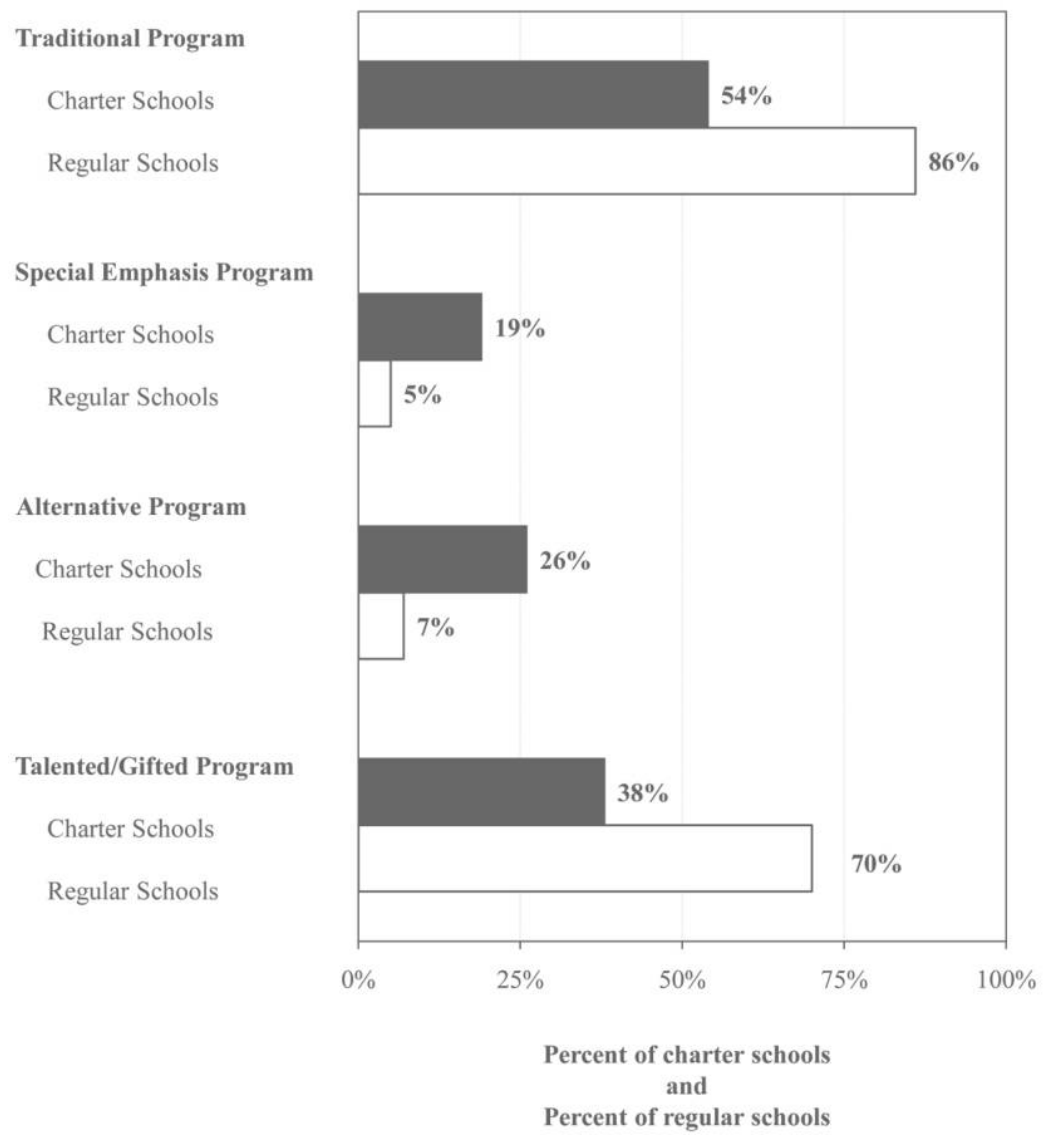

Fig. 2.-Percentages of charter schools and regular public schools by type in states with charter schools. Note: Special Program Emphasis includes science/math schools, performing arts high school, foreign language immersion schools, talented/gifted schools, and so forth. Values do not add up to 100 percent because special education and vocational/technical programs were omitted and because talented/gifted programs can occur in schools offering traditional, special emphasis, and alternative programs. Data source: 2003-4 Schools and Staffing Survey, NCES, USDE. 
provide talented/gifted programs $(\mathrm{OR}=2.0, p<.01)$, whereas large regular schools were five times more likely to provide such programs than large charter schools $(\mathrm{OR}=5.0, p<.001)$. These analyses indicated that a substantially greater percentage of regular schools than charter schools provided talented/ gifted programs regardless of school size.

Another possible reason for the disparity in talented/gifted programs between charter and regular schools is that, on average, charter and regular schools serve different student populations. ${ }^{5}$ Past research suggests that schools serving affluent student populations offer more enriched programs of study such as talented/gifted programs (e.g., Baker and Friedman-Nimz 2002). This finding, however, was not replicated in our sample. Using the percentage of students approved for the National School Lunch Program as a proxy for average student socioeconomic status (SES) at the schools, we found equivalent percentages of approved students in both charter (37 percent) and regular (40 percent) schools. ${ }^{6}$ Adjusting for SES did not reduce the gap between regular and charter schools in the percentage that provided talented/gifted programs - the unadjusted OR was 3.8; with control for SES, the adjusted OR was $4.0(p<.001)$.

\section{School Options: Nontraditional Classrooms}

With respect to the charter school legislative objective to provide more school options at the classroom level, figure 3 shows the percentage of charter and regular schools using nontraditional classroom options, such as special instructional approaches, looping, block scheduling, and the placement of students into small groups. In general, charter schools were much more likely to implement nontraditional classroom options than regular schools. For example, they were three times more likely than regular schools to use special instructional approaches $(\mathrm{OR}=3.2, p<.001)$. This difference was similar among both elementary and secondary schools $(\mathrm{OR}=3.2$ vs. 3.6, respectively, both ORs significant at $p<.001)$. However, no such difference was found in schools that offer all grade levels.

Charter schools were also much more likely than regular schools to use looping $(\mathrm{OR}=2.3, p<.001)$. The difference between charter and regular schools in terms of looping occurred among elementary schools $(\mathrm{OR}=2.7$, $p<.001)$. However, differences in looping did not occur among secondary schools $(\mathrm{OR}=1.6, p=.45)$.

Charter schools were also more likely to use block scheduling than regular schools $(\mathrm{OR}=1.7, p<.01)$. The difference between charter and regular schools in terms of block scheduling occurred among elementary schools (OR $=1.9, p<.05)$ but not among secondary schools $(\mathrm{OR}=1.1, p=.86)$. 
Special Instructional Approach

\section{Charter Schools}

Regular Schools

Looping

Charter Schools

Regular Schools

Block Scheduling

Charter Schools

Regular Schools

Small Student Groups

Charter Schools

Regular Schools

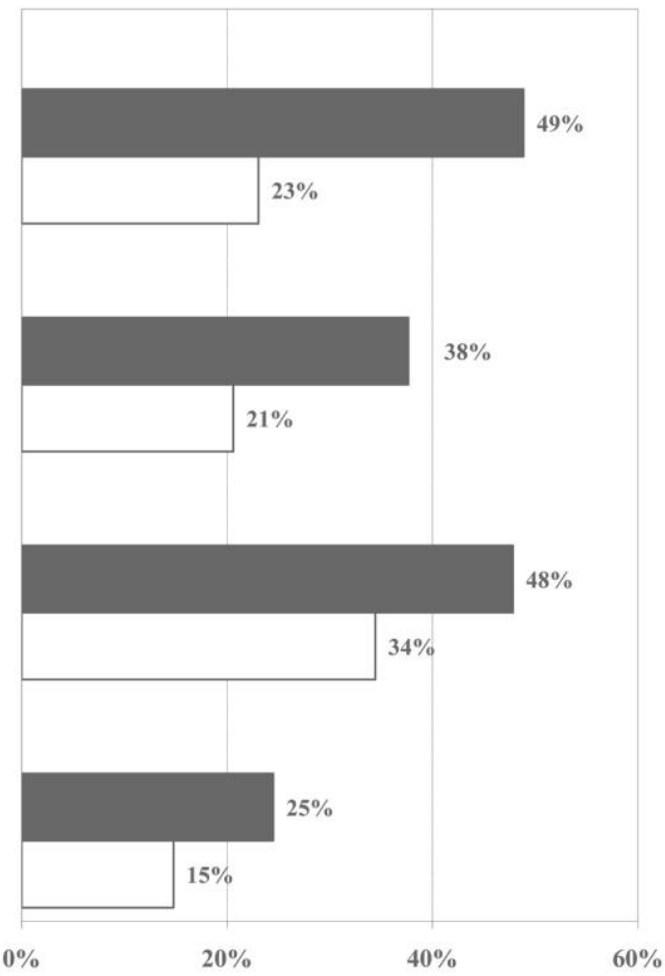

Percent of charter schools and

Percent of regular schools

FIG. 3.-Percentages of charter and regular public schools offering nontraditional classroom options in states with charter schools. Note: Special instructional approach includes Montessori, self-paced instruction, and so forth. Looping refers to keeping students with the same teacher for two or more years. Block scheduling refers to class periods scheduled to create extended instructional time. Small student groups refers to subdividing grades into smaller groups. Values do not add up to 100 percent because implementing classroom options is not mutually exclusive. Data source: 2003-4 Schools and Staffing Survey, NCES, USDE. 
Finally, charter schools were about twice as likely as regular schools to place students in small student groups $(\mathrm{OR}=1.9, p<.001)$. This difference also occurred among elementary schools $(\mathrm{OR}=2.2, p<.01)$ but not among secondary schools $(\mathrm{OR}=1.3, p=.45)$.

\section{Teacher Influence over Decision Making}

With respect to the charter school legislative objective to increase teacher influence over decision making, we compared the reports of charter and regular school teachers about their general influence over school operations (see fig. 4). Charter school teachers were more than twice as likely as regular school teachers to report they have "considerable influence" over school operations as compared with "little influence" $(\mathrm{OR}=2.2, p<.001)$. In absolute terms, 31 percent of charter school teachers reported having moderate or greater influence over school operations, while only 13 percent of regular school teachers reported so. It appears that charter school teachers have experienced somewhat greater influence over school operations than regular school teachers.

Teachers come from different ethnic backgrounds and have different levels of education, working experiences, and connections to the teaching profession. Others have noted these factors might lead to differing perceptions of influence over decision making (Rowan, Raudenbush, and Kang 1991). Thus, we added controls for race, gender, teaching experience, education level, and union membership to the analysis above. ${ }^{7}$ With these additional controls, charter school teachers were still more than twice as likely as regular school teachers to report they have "considerable influence" over school operations as compared with "little influence" (adjusted OR $=2.1, p<.001$ ).

We also examined how much influence teachers reported having in their classroom over (1) curriculum-related decisions such as selecting the content, topics, and skills taught and (2) their instructional technique. Charter school teachers were marginally more likely than regular school teachers to report they have "considerable control" over their curriculum as compared with "little control" (OR $=1.4, p<.01)$. In absolute terms, 50 percent of charter school teachers reported having considerable control over curriculum compared with 42 percent of regular school teachers. However, charter and regular school teachers were equally likely to report "considerable control" over their instructional technique as compared with "little control" $(\mathrm{OR}=.70, p=$ .26). It appears charter school teachers have experienced slightly greater influence over the curriculum they teach than regular school teachers, but both reported high levels of control over instruction. 


\section{Charter School Legislative Objectives}

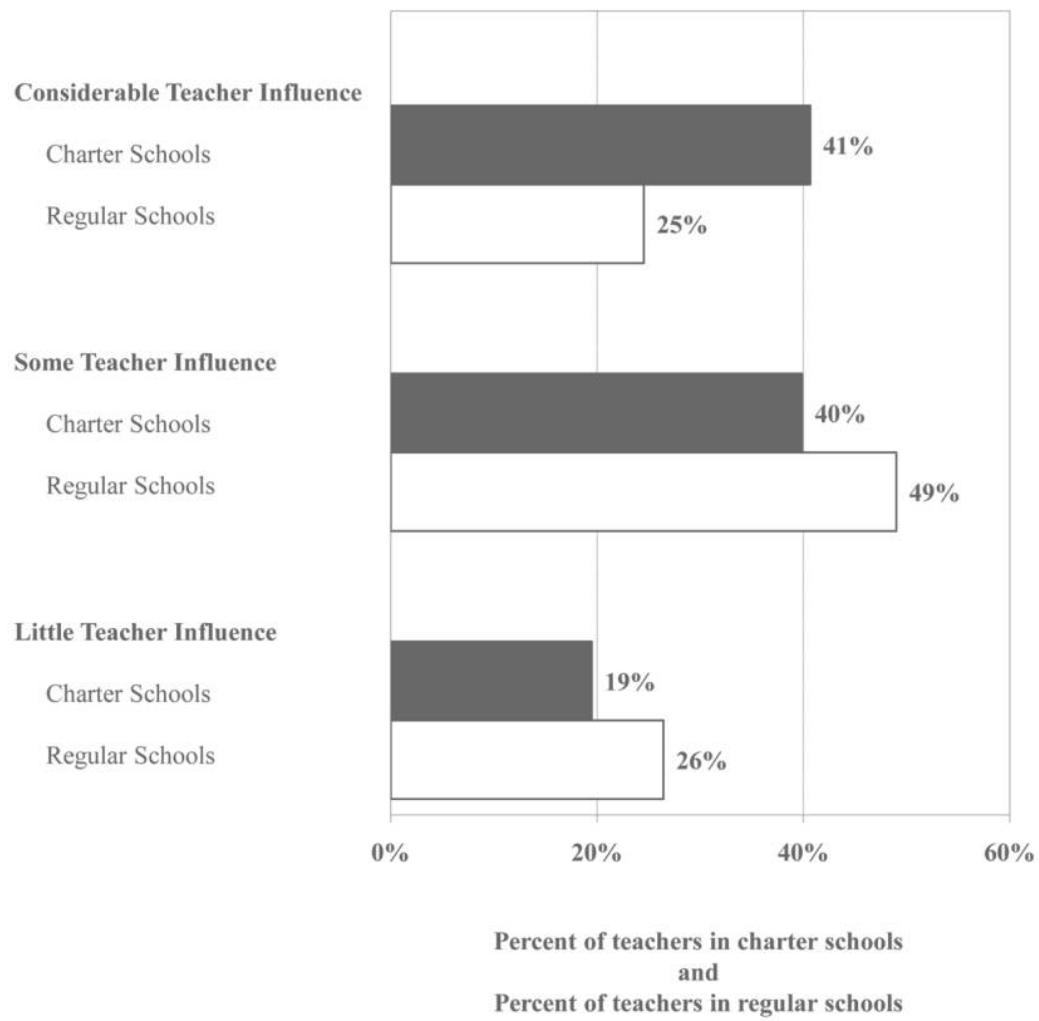

FIG. 4.-Percentages of teachers in charter and regular school who report considerable, some, and little influence over decision making. Note: Teachers assessed their influence over seven areas of school operations. Answers ranged from "no influence" to "a great deal of influence." A summative index was then created from these seven variables $(\alpha=.81)$. Data source: $2003-4$ Schools and Staffing Survey, NCES, USDE.

\section{School Autonomy}

With respect to the charter school legislative objective to increase school autonomy, we compared charter and regular school principals' reports about the level of influence asserted by the state and district over school operations (see figs. 5 and 6, respectively). Charter school principals were more than twice as likely as regular school principals to report that the state has "little influence" over their school's operations as compared with "considerable influence" (OR $=2.1, p<.02)$. In absolute terms, 24 percent of charter school 
Considerable State Influence

Charter Schools

Regular Schools

Some State Influence

Charter Schools

Regular Schools

Little State Influence

Charter Schools

Regular Schools

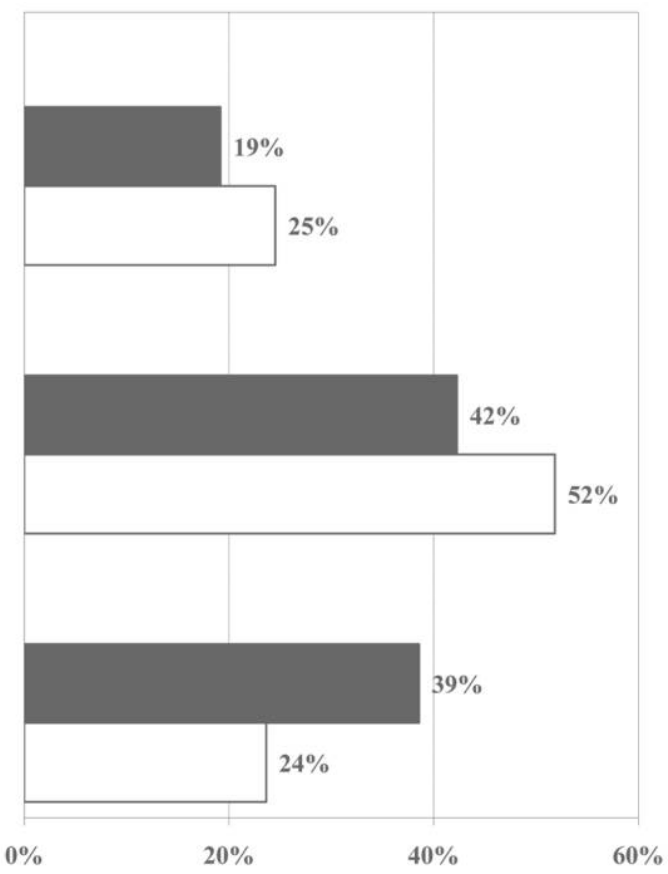

Percent of principals in charter schools and

Percent of principals in regular schools

FIG. 5.-Percentages of charter and regular school principals who report considerable, some, and little state influence over school operations. Note: Principals assessed their state's department of education's influence over seven areas of school operations. Answers ranged from "minor influence" to "major influence." A summative index was created from these seven variables $(\alpha=.77)$. Data source: 2003-4 Schools and Staffing Survey, NCES, USDE.

principals reported that the state had only minor or less influence over school operations, while only 12 percent of regular school principals reported so.

Charter school principals were also twice as likely as regular school principals to report that the district has "some influence" over their school's operations as compared with "high influence" $(\mathrm{OR}=2.0, p<.01)$. In absolute terms, 18 percent of charter school principals and only 4 percent of regular school principals reported that the district had only minor or less influence over school operations. It appears that, in practice, charter school principals 


\section{Charter School Legislative Objectives}

High District Influence

Charter Schools

Regular Schools

Considerable District Influence

Charter Schools

Regular Schools

Some District Influence

Charter Schools

Regular Schools

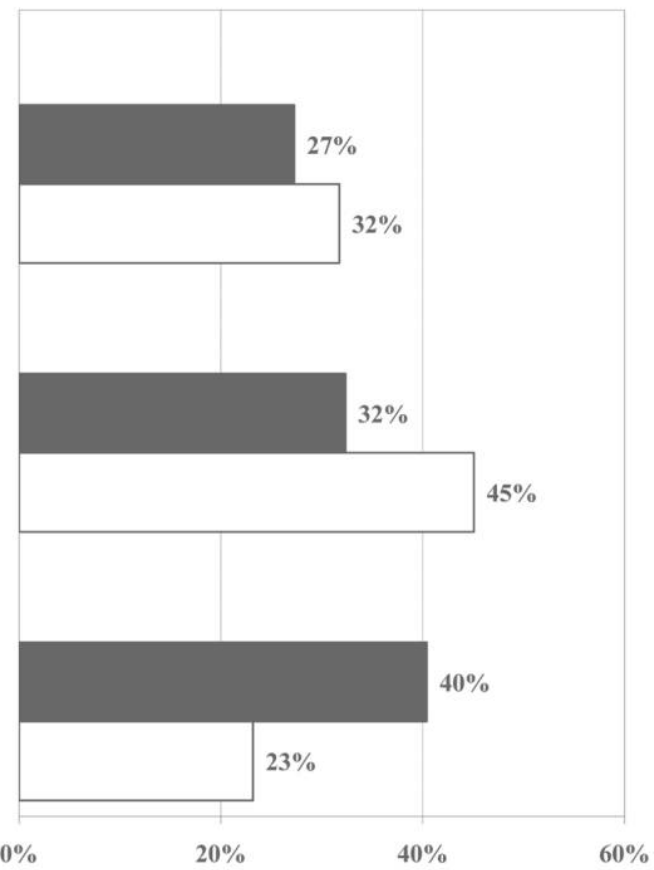

Percent of principals in charter schools and

Percent of principals in regular schools

FIG. 6.-Percentages of charter and regular school principals who report high, considerable, and some district influence over school operations. Note: Principals assessed the district's influence over seven areas of school operations. Answers ranged from "minor influence" to "a great deal of influence." A summative index was created from these seven variables $(\alpha=.78)$. Data source: 2003-4 Schools and Staffing Survey, NCES, USDE.

experience somewhat more autonomy from state and district influence than regular school principals.

\section{Discussion}

We designed this research to provide new information about the implementation of several prominent charter school legislative objectives. The results are discussed first in terms of these objectives. 


\section{Provide More School Options and Nontraditional Classrooms}

In keeping with their legislative objectives, we found that charter schools, in comparison with regular schools, were considerably more likely to offer alternative programs, special emphasis programs, and a variety of nontraditional classroom options. In contrast, regular schools were much more likely to offer a traditional educational program than charter schools. With respect to nontraditional classrooms, we found that charter schools were more likely to use looping, block scheduling, and small student groups than regular schools, but only in elementary schools. However, charter schools were much less likely to offer gifted/talented programs (even after adjusting for school SES and size). By using recent and the best national data available, our results provide substantial evidence that charter schools offer more types of schools and nontraditional classroom options than regular schools. Thus, charter schools nationally have largely been implemented in accordance with this legislative objective.

The robustness of our results about the differences between charter and regular schools in terms of school and classroom options significantly advances knowledge about charter schools. For example, two recent literature reviews (Bulkley and Fisler 2003; Gill et al. 2007) concluded that it was unclear whether charter schools offer more school and classroom options than regular schools. In an earlier study using the 2003-4 SASS data, Strizek et al. (2006) reported that charter schools offered a wider variety of nontraditional classroom options than regular schools. However, these researchers noted that more sophisticated analyses could be conducted with the restricted-use SASS data. Accordingly, we used the restricted-use SASS data to refine and expand on the analytic methods used by Strizek et al. (2006) in three ways. First, whereas Strizek et al. compared all charter schools to all regular schools in the United States, we only compared charter schools and regular schools in states with charter schools to make more accurate comparisons. Second, we calculated an effect size statistic (i.e., OR) and tested the statistical significance for each difference between charter and regular schools using logistic regression. Third, we controlled statistically for potentially confounding variables in analyzing talented/ gifted programs and we controlled for school level in analyzing classroom options.

\section{Increase Teacher Influence over Decision Making}

Another prominent objective of charter school legislation is to afford teachers more influence over decision making so they can better attend to student needs, and thereby improve student achievement (Gawlik 2007). Our results 


\section{Charter School Legislative Objectives}

indicate that charter school teachers have experienced greater influence over school operations than regular school teachers. However, charter school teachers reported only slightly more influence than regular school teachers over the curriculum they teach, and teachers from both types of schools reported having a great deal of freedom to select their instructional methods. Thus, our results show that charter schools were modestly successful in providing teachers with a greater level of influence over decision making compared to what regular school teachers experience. Though consistent with the intent of charter school legislation, the magnitude of our results suggests this objective has not been fully realized in practice. According to a recent literature review (Gawlik 2007), the extent to which teachers experience greater influence over decision making within charter schools is unknown. Thus, our results regarding the differences between charter and regular schools in terms of teacher influence represent a significant advance in knowledge.

\section{Increase School Autonomy}

Charter schools fundamentally represent a trade-off-greater autonomy for increased accountability (Finnigan 2007). Curiously, 72 percent of states with charter school legislation specify more accountability as an objective, while only 27 percent of such states specify increased autonomy (Smarick 2005). Autonomy frees charter schools from a number of constraints normally placed on personnel, financial, and curricular decisions, and this freedom is thought to lead to improved student achievement (Gawlik 2007). Without substantial autonomy, charter schools can neither provide more educational options (Bulkley and Fisler 2003) nor increase teacher influence over decision making.

Our results indicate charter school principals have experienced considerably less state and district influence over school operations than regular school principals. This result is consistent with the intent of charter school legislation. It should also be expected, because DC and 14 of the 17 states in our sample have strong charter school laws. For the most part, these laws intend to free charter schools from regulations governing the operation of the school and allow them to become independent legal entities with regard to budget, personnel, and so forth (CER 2006). However, only 39 percent of charter school principals experienced little state influence, and only 18 percent experienced little district influence over school operations. Thus, although charter school principals experienced greater autonomy than regular school principals, a high level of autonomy has not been achieved in practice.

Our results provide substantial new information about the level of autonomy of charter schools from state and local policy. In part, they corroborate Finnigan's (2007) finding that charter schools do not experience a very high level 
of autonomy. Our findings extend the literature on charter school autonomy by providing a comparison with regular schools. The results reported here suggest that charter school teachers and principals have not experienced the level of autonomy over school operations intended in authorizing state legislation. Policy makers and charter school leaders should examine this policy and management issue.

Finally, autonomy is inextricably linked to accountability in charter school rhetoric and politics - greater autonomy for increased accountability (Finnigan 2007). Though the SASS is unique in the diversity of questions it asks and the various sources from which it gathers information, it does not, unfortunately, address accountability well, and therefore we did not analyze this here. Further research should collect in-depth information on this topic by surveying both charter and regular schools about the role of testing in their operations, for example. This would provide some indication of whether charter schools pay more attention to accountability than regular schools.

\section{Implications for Student Achievement}

The extent to which charter schools improve student achievement has been the focus of much research and the source of much debate. Results from studies of student achievement are very mixed with some reporting positive results (Hoxby and Murarka 2008; Hoxby and Rockoff 2005; Vanourek 2005), some negative (Bracey 2005; Carnoy et al. 2005), and the majority finding no or mixed results (e.g., Center for Research on Education Outcomes [CREDO] 2009; Gill et al. 2007; Miron and Nelson 2001). Furthermore, when a positive or negative impact on achievement was detected, only a small difference was seen between charter schools and the comparison group (typically, regular schools; for a review see Hill et al. 2006).

Mixed results were also found in the first large-scale randomized trial of the effectiveness of charter schools (Gleason et al. 2010). The evaluation compared the outcomes of 2,330 students in 36 charter middle schools in 15 states who were randomly admitted to the charter schools to those not admitted. On average, there was no difference in math or reading test scores between charter and regular middle schools, but the results varied significantly by school (Gleason et al. 2010). The effects on reading scores were positive in 11 sites and negative in 17 , and the effects on math scores were positive in 10 sites and negative in 18 (Gleason et al. 2010).

It is possible that new studies, using rigorous methods to assess causality and disaggregating the data in important ways, may find more consistent results. However, without a current body of evidence showing that charter schools improve academic achievement above that attained in regular schools, 


\section{Charter School Legislative Objectives}

it is imperative to know why this major legislative objective is not being attained. One possible explanation for this outcome is that charter schools have not been implemented according to their main legislative objectives. However, our results suggest otherwise. We found that compared to regular schools, charter schools nationally (1) offered more educational options, (2) provided somewhat more influence over decision making to teachers, and (3) provided somewhat more autonomy to schools from state and local policies. However, with respect to the latter two points, we also found that charter school teachers' influence over decision making and school autonomy, although greater than that found in regular schools, were not very high in an absolute sense. Still, it appears charter schools nationally have been implemented as intended to a considerable degree.

The results of this study suggest the charter school concept may be an inadequate means to improve student achievement. According to the USDE (2004a), providing more choices by establishing charter schools "will result in higher student achievement, however, only if sufficiently diverse and highquality choices, and genuine opportunities to take advantage of those choices, are available to all students" (2). Our results show the choices offered by charter schools are considerably more diverse than those offered by regular schools. However, research has yet to provide evidence about the relative quality of charter schools. Given the general ineffectiveness of charter schools to improve achievement more so than regular schools, it can be hypothesized that charter schools have not offered higher quality choices than regular schools, even though they have generally been implemented as intended.

Alternatively, it could be argued that charter schools have been successful, because their students' achievement is equivalent to that of regular school students. Based on the findings of the review of research on achievement in charter schools by Hill et al. (2006), Smarick (2008) concluded that "research on student achievement in charters is encouraging" (40). Another perspective is that every charter school should be viewed as an experiment, some of which should be expected to fail and others to succeed (Carnoy et al. 2005). From this view, the fact that charter and regular school students attain equivalent levels of achievement, on average, is encouraging.

\section{Outcomes Other than Achievement}

It may be that using academic achievement as the primary indicator of the success of charter schools is too narrow, because these schools purport to do much more than improve achievement. For example, charter schools may improve nonacademic outcomes such as attendance, behavior, and graduation rates. They may also increase parental involvement and satisfaction. Fur- 
thermore, if charter schools do not generally improve student achievement in comparison with regular schools, why has the number of charter schools grown so rapidly since their inception in 1992? In a review of survey literature, Bulkley and Fisler (2003) found that parents of charter school students are generally satisfied with their child's charter school. In the aforementioned randomized trial, Gleason et al. (2010) found that being admitted to a charter middle school significantly improved student and parental satisfaction with school. In a study in Texas of why parents select charter schools for their students, Weiher and Tedin (2002) found that the parents attached much more importance to moral values, discipline, and safety offered by charter schools than achievement scores. In addition to offering expanded choices of promising educational programs and nontraditional classroom options (as intended by charter school legislation), charter schools seem to provide a highly valued alternative to problem-ridden regular schools.

In research that included nonacademic outcomes of charter schools, Imberman (2007) studied a large urban school district and found that "schools that begin as charters (startup charters) are effective in improving student behavior and attendance, although they have no statistically significant impact on test scores" (26). Further study of such measureable outcomes of charter schools, other than achievement and parent satisfaction, will go far to delineate the benefits of charter schools. This will help explain the strong appeal of charter schools to thousands of families, many of whom populate lengthy waiting lists for admission (Smarick 2008).

Thus, the social and behavioral benefits of charter schools - not improvements in student achievement - may become the primary justification for continuing this education reform. As evidenced by their appeal to large numbers of families, charter schools obviously have much of value to offer. It is important to know more about this in efforts to improve both charter and regular schools.

\section{Implications for Charter School Research}

The results reported here are also important to identify lines of further research. First, more research should be devoted to understanding why the charter school model has not improved student achievement. Second, research on the quality of educational programs offered by charter schools compared with regular schools is needed. Third, further investigation should be made into why the increased autonomy from the states and districts has not produced more effective charter schools. A pillar of the charter school concept is that autonomy frees charter schools from myriad constraints, and this freedom produces better schools that in turn improve achievement. It is therefore 


\section{Charter School Legislative Objectives}

important to investigate how teachers and principals use increased autonomy, if increased autonomy can be used more effectively, and how autonomy impacts outcomes. Fourth, further research is needed on the degree to which the charter school movement has increased accountability, especially in an era of increasing standardization and accountability in the regular school system. Finally, future research should investigate the implementation of other charter school legislative objectives (such as increased accountability and more professional options for teachers) that we and others have not been able to address. Pursuing this research agenda will help us to better understand how well the charter school concept (as intended in state legislation) has been implemented and the consequences for improving student achievement.

\section{Notes}

Support for this research was provided to Katherine M. Barghaus through a Greenblatt doctoral fellowship and by the Center for Research and Evaluation in Social Policy, the Graduate School of Education of the University of Pennsylvania. The research reported here was also supported by the Institute of Education Sciences, U.S. Department of Education, through grant R305B090015 of the U.S. Department of Education. The views expressed in this article are solely those of the authors.

1. We selected these three prominent charter school objectives for investigation because of the availability of relevant high-quality national data. Other objectives (e.g., increase school accountability) identified by Smarick (2005) were not included due to data limitations.

2. We also conducted a preliminary analysis using the 1999-2000 wave of the SASS. In general, the results of this analysis followed the same trends we report here for the 2003-4 data.

3. In addition to collecting data on talented/gifted programs, SASS also collected data on foreign language immersion programs. Since fewer than 10 charter schools in the data offered a foreign language program, there was no further analysis.

4. These cut points were selected to insure a sufficient sample of both small and large schools.

5. Two other possible explanations for regular schools being more likely to offer talented/gifted programs than charter schools are that (1) charter schools may be less likely to use academic tracks and (2) talented/gifted programs are expensive and charter schools generally have smaller budgets than regular schools (Anderson et al. 2003).

6. Using free lunch as a proxy for average student SES is not ideal. However, a large number of studies have used this proxy because it is typically the only relevant variable collected in education surveys.

7. The race variable had four categories: non-Hispanic white, non-Hispanic black, Hispanic, and other non-Hispanic. The teaching experience variable had three categories that included 0-3 years of experience, 4-9 years, and 10 or more years. The education variable was a dichotomous variable that equaled one if the teacher had a masters degree and zero if they had a bachelors degree. Finally, union membership was also a dichotomous variable that equaled one if the teacher was a union member and zero if not. 


\section{Barghaus and Boe}

\section{References}

American Federation of Teachers (AFT). 2002. Do Charter Schools Measure Up? The Charter School Experiment after 10 Years. Washington, DC: AFT.

Anderson, Lee, Nancy Adelman, Kara Finnigan, Lynyonne Cotton, Mary Beth Donnelly, and Tiffany Price. 2002. A Decade of Public Charter Schools Evaluation of the Public Charter Schools Program: 2000-2001 Evaluation Report. Menlo Park, CA: SRI.

$\rightarrow$ Baker, Bruce D., and Reva Friedman-Nimz. 2002. "Determinants of the Availability of Opportunities for Gifted Children: Evidence from NELS 88." Leadership and Policy in Schools 1 (1): 52-71.

$\rightarrow$ Bettinger, Eric P. 2005. "The Effect of Charter Schools on Charter Students and Public Schools." Economics of Education Review 24 (2): 133-47.

Bomotti, Sally, Rick Ginsberg, and Brian Cobb. 1999. "Teachers in Charter Schools and Traditional Schools: A Comparative Study." Education Policy Analysis Archives 7 (July): 1-27, http://epaa.asu.edu/epaa/v7n22.html.

Bracey, Gerald W. 2005. Charter Schools' Performance and Accountability: A Disconnect. Tempe: Education Policy Studies Laboratory, Arizona State University, http://epicpolicy .org/files/EPSL-0505-113-EPRU.pdf.

Brinson, Dana, and Jacob Rosch. 2010. Charter School Autonomy: A Half-Broken Promise. Washington, DC: Fordham.

Budde, Ray. 1988. Education by Charter: Restructuring School Districts. Andover, MA: Regional Laboratory for Educational Improvement of the Northeast and Islands.

Bulkley, Katrina, and Jennifer Fisler. 2002. A Review of the Research on Charter Schools. Consortium for Policy Research in Education [CPRE] Web Paper Series (WP-01). Philadelphia: CPRE, University of Pennsylvania, Graduate School of Education.

$\rightarrow$ Bulkley, Katrina, and Jennifer Fisler. 2003. "A Decade of Charter Schools: From Theory to Practice." Educational Policy 17:317-42.

Carnoy, Martin, Rebecca Jacobsen, Lawrence Mishel, and Richard Rothstein. 2005. The Charter School Dust Up: Examining the Evidence on Enrollment and Achievement. Washington, DC: Economic Policy Institute.

Center for Education Reform (CER). 2006. Charter Schools Today: Changing the Face of American Education. Part 2: Raising the Bar on Charter School Laws 2006 Ranking and Scorecard (9th ed.). Washington, DC: CER.

Center for Education Reform (CER). 2009. National Charter School and Enrollment Statistics 2009. Washington, DC: CER.

Center for Research on Education Outcomes (CREDO). 2009. Multiple Choice: Charter School Performance in 16 States. Palo Alto, CA: Stanford University.

$\rightarrow$ Crawford, James R. 2001. "Teacher Autonomy and Accountability in Charter Schools." Education and Urban Society 33 (February): 186-200.

Crawford, James R., and Patrick B. Forsyth. 2004. "Teacher Empowerment and Charter Schools." Fournal of School Leadership 14 (1): 55-84.

$\rightarrow$ Cronbach, Lee J. 1951. "Coefficient Alpha and the Internal Structure of Tests." Psychometrika 16:297-334.

Dirkswager, Edward J. 2002. Teachers as Owners: A Key to Revitalizing Public Education. Blue Ridge Summit, PA: Scarecrow.

Division of Charter Schools and Texas Education Agency. 2007. Texas Open-Enrollment Charter Schools: 2005-6 Evaluation. Austin: Texas Center for Educational Research.

$\rightarrow$ Finnigan, Kara S. 2007. "Charter School Autonomy: The Mismatch between Theory and Practice." Educational Policy 21:503-26. 


\section{Charter School Legislative Objectives}

$\rightarrow$ Gawlik, Marytza A. 2007. "Beyond the Charter School House Door: Teacher-perceived Autonomy." Education and Urban Society 39:524-53.

$\rightarrow$ Gawlik, Marytza A. 2008. "Breaking Loose: Principal Autonomy in Charter and Public Schools." Educational Policy 22:783-804.

Gifford, Mary, Karla Phillips, and Melinda Ogle. 2000. Five Year Charter School Study: An Overview. Arizona Education Analysis. Phoenix: Gold-Water Institute, Center for Market-Based Education.

Gill, Brian P., Mike Timpane, Karen E. Ross, and Dominic J. Brewer. 2007. Rhetoric vs. Reality: What We Know and What We Need to Know about Vouchers and Charter Schools (updated ed.). Santa Monica, CA: RAND.

Gleason, Philip, Melissa Clark, Christina C. Tuttle, and Emily Dwoyer. 2010. The Evaluation of Charter School Impacts: Executive Summary (NCEE 2010-4030). Washington, DC: National Center for Education Evaluation and Regional Assistance, Institute of Education Sciences, U.S. Department of Education.

$\rightarrow$ Hill, Paul T., Lawrence Angel, and Jon Christensen. 2006. "Charter School Achievement Studies." Education Finance and Policy 1 (Winter): 139-50.

Hosmer, David W., and Stanley Lemeshow. 2000. Applied Logistic Regression (2nd ed.). New York: Wiley.

Hoxby, Caroline M., and Sonali Murarka. 2008. "New York City Charter Schools: Who Attends Them and How Well Are They Teaching Their Students?" Education Next 8 (Summer): 54-61.

Hoxby, Caroline M., and Jonah E. Rockoff. 2005. The Impact of Charter Schools on Student Achievement. Cambridge, MA: Harvard University Press.

Imberman, Scott A. 2007. "Achievement and Behavior in Charter Schools: Drawing a More Complete Picture." Working Paper, University of Houston, http://www .ncspe.org/publications_files/OP142.pdf.

$\rightarrow$ Lubienski, Christopher. 2003. "Innovation in Education Markets: Theory and Evidence on the Impact of Competition and Choice in Charter Schools." American Educational Research Fournal 40:395-443.

Malloy, Courtney L., and Priscilla Wohlstetter. 2003. "Working Conditions in Charter Schools: What's the Appeal for Teachers?" Education and Urban Society 35 (February): 219-41.

May, Henry. 2004. "JACKREG: SAS Macro for Use with the SAS System, ver. 4.0." Philadelphia: University of Pennsylvania, http://www.gse.upenn.edu/hmay/.

Mintrom, Michael. 2000. Leveraging Local Innovation: The Case of Michigan's Charter Schools. Lansing: Michigan State University, Department of Political Science.

Miron, Gary, and Jerry Horn. 2003. Evaluation of Connecticut Charter Schools and the Charter School Initiative: Final Report. Kalamazoo: Western Michigan University, Evaluation Center.

Miron, Gary, and Christopher Nelson. 2000. Autonomy in Exchange for Accountability: An Initial Study of Pennsylvania Charter Schools. Kalamazoo: Western Michigan University.

Miron, Gary, and Christopher Nelson. 2001. "Student Academic Achievement in Charter Schools: What We Know and Why We Know So Little." Occasional Paper 41. New York: Teachers College, Columbia University, National Center for the Study of Privatization in Education.

$\rightarrow$ Nathan, Joe. 1998. "Heat and Light in the Charter School Movement." Phi Delta Kappan 79 (7): 499-505.

National Assessment of Educational Progress (NAEP). 2008. Glossary, http://nces.ed .gov/nationsreportcard/glossary.asp\#c.

National Charter School Research Project. 2007. Inside Charter Schools: A Systematic Look 


\section{Barghaus and Boe}

at Our Nation's Charter Schools. Seattle: Center on Reinventing Public Education, University of Washington.

$\rightarrow$ Rowan, Brian, Steve W. Raudenbush, and Sang Jin Kang. 1991. "Organizational Design in High Schools: A Multilevel Analysis." American Fournal of Education 99 (February): 238-66.

RPP International. 2000. The State of Charter Schools 2000 - Fourth Year Report. Washington, DC: Office of Educational Research and Improvement, U.S. Department of Education.

Sautter, Graig R. 1993. Charter Schools: A New Breed of Public Schools (Report 2). Oak Brook, IL: North Central Regional Educational Laboratory.

Schroeder, Jon. 2004. Ripples of Innovation: Charter Schooling in Minnesota, the Nation's First Charter School State. Washington, DC: Progressive Policy Institute, http://www .ppionline.org/documents/MN_Charters_0504.pdf

Shanker, Albert. 1988. "Restructuring Our Schools." Peabody Fournal of Education 65 (Spring): 92-98.

Smarick, Andy. 2005. Original Intent: What Legislative History Tells Us about the Purposes of Chartering. Washington, DC: National Alliance for Public Charter Schools.

Smarick, Andy. 2008. "Wave of the Future: Why Charter Schools Should Replace Failing Urban Schools." Education Next 8 (Winter): 39-45.

Strizek, Gregory A., Jayme L. Pittsonberger, Kate E. Riordan, Deanna M. Lyter, and Greg F. Orlofsky. 2006. Characteristics of Schools, Districts, Teachers, Principals, and School Libraries in the United States: 2003-4 Schools and Staffing Survey (NCES 2006-313 Revised). Washington, DC: U.S. Department of Education, National Center for Education Statistics, U.S. Government Printing Office.

Teske, Paul, Mark Schneider, Jack Buckley, and Sara Clark. 2000. Does Charter School Competition Improve Traditional Public Schools? New York: Manhattan Institute for Policy Research.

Tourkin, Steven C., Toni Warner, Randall Parmer, Cornette Cole, Betty Jackson, Andrew Zukerberg, Shawna Cox, and Andrew Soderberg. 2007. Documentation for the 2003-4 Schools and Staffing Survey (NCES 2007-337). Washington, DC: U.S. Department of Education, National Center for Education Statistics.

Triant, Bill. 2001. Autonomy and Innovation: How Do Massachusetts Charter School Principals Use Their Freedom? Washington, DC: Thomas B. Fordham Foundation.

U.S. Department of Education. 2000. Evaluation of the Public Charter Schools Program: Year One Evaluation Report. Washington, DC: U.S. Department of Education, Office of the Under Secretary, Planning and Evaluation Service, Elementary and Secondary Program Division.

U.S. Department of Education. 2004a. Non-Regulatory Guidance, Title V, Part B, Charter Schools Program. Jessup, MD: ED Pubs.

U.S. Department of Education. 2004b. Evaluation of the Public Charter Schools Program: Final Report. Washington, DC: USDE.

U.S. Department of Education. 2007. 2003-4 Schools and Staffing Survey (SASS) CD-ROM: Restricted-Use Data with Electronic Codebook (data file). Washington, DC: USDOE, NCES.

Vanourek, Gregg. 2005. State of the Charter Movement 2005: Trends, Issues, and Indicators. Washington, DC: Charter School Leadership Council.

$\rightarrow$ Weiher, Gregory R., and Kent L. Tedin. 2002. "Does Choice Lead to Racially Distinctive Schools? Charter Schools and Household Preferences." Journal of Policy Analysis and Management 21 (1): 79-92.

Wells, Amy S., Ligia Artiles, Sibyll Carnochan, Camille W. Cooper, Cynthia Grutzik, Jennifer J. Holme, Alejandra Lopez, Janelle Scott, Julie Slayton, and Ash Vasudeva. 


\section{Charter School Legislative Objectives}

1998. Beyond the Rhetoric of Charter School Reform: A Study of Ten California School Districts. Los Angeles: UCLA Charter School Study.

Westat, Inc. 2002. WesVar software, version 4.2. Rockville, MD: Westat.

Zimmer, Ron, Richard Buddin, Derrick Chau, Glenn A. Daley, Brian Gill, Cassandra M. Guarino, Laura S. Hamilton, Cathy Krop, Daniel F. McCaffrey, Melinda Sandler, and Dominic J. Brewer. 2003. Charter School Operations and Performance: Evidence from California. Santa Monica, CA: RAND. 